\title{
Green roof performance under malaysia tropical climates: a review
}

\author{
Nur Fitriah Isa ${ }^{1}$, Hartini Kasmin ${ }^{2}$, Norhaizura Yahya ${ }^{3}$, Mustaqqim Abdul Rahim ${ }^{4}$, \\ Zuhayr Md Ghazaly ${ }^{5}$ \\ ${ }^{1,3}$ Faculty of Engineering Technology, Universiti Malaysia Perlis (UniMAP), Malaysia \\ ${ }^{1,2}$ Faculty of Civil and Environmental Engineering, Universiti Tun Hussein Onn Malaysia (UTHM), Malaysia \\ ${ }^{4,5}$ School of Environmental Engineering, Universiti Malaysa Perlis (UniMAP), Malaysia
}

\begin{tabular}{|c|c|}
\hline Article Info & ABSTRACT \\
\hline & \multirow{8}{*}{$\begin{array}{l}\text { Green roof system is one of sustainable approach for energy consumption } \\
\text { reduction and improving the aesthetic value of the built environment. } \\
\text { The system has been adopted by most of developed countries; and in Malaysia, } \\
\text { research on green roof studies are quite evolving however the implementation } \\
\text { of the system is slow due to some perceptions and obstacles. Green roof has } \\
\text { potential on providing benefits such as reduction on the urban heat island } \\
\text { effect, reduces temperatures, pollution and improves the attenuation of } \\
\text { stormwater. This paper will highlights on a preliminary review of the } \\
\text { implementation green roof system in Malaysia and explores the performances } \\
\text { of Malaysian green roof in order to highlight the performance of green roof } \\
\text { under tropical climatic conditions using local configurations. }\end{array}$} \\
\hline Received Aug 3, 2019 & \\
\hline Revised Oct 25, 2019 & \\
\hline Accepted Nov 9, 2019 & \\
\hline Keywords: & \\
\hline Green roof & \\
\hline Performance & \\
\hline Storm water & \\
\hline
\end{tabular}

Sustainable development

Tropical climate

\section{Corresponding Author:}

Name Nur Fitriah Isa,

Department of Civil Engineering Technology,

Faculty of Engineering Technology,

Universiti Malaysia Perlis (UniMAP), 02100 Perlis, Malaysia.

Email: nurfitriah@unimap.edu.my

\section{INTRODUCTION}

Globally, urbanization has becoming a threat to the environmental issues. Urbanisation has led to the acceleration of numerous environmental problems in most developed countries especially in developing countries such as Malaysia. The environmental problems are mainly due to the production of pollution, modification the physical and chemical properties of soil, air and water [1], and transform the natural landscape to anthropogenic urban land and changes surface physical characteristics [2].

Most of urban facilities use energy resouces for industrial, transport sector for burning fuels such as natural gases, oil, and coal; and has led these usage to the increment of gaseous concentration and particle pollutants in the atmosphere [3]. Hence, acid rain has become the most serious problems and gives serious impact on soil parameters, on aquatic ecosystem, on forest trees, on crop plants, on lower plants, on materials and buildings, on animals, on human health [4-8]. Buildings, streets, and driveways are replacing grasslands and forests, which also causes the increment in the rainwater runoffs volume that generates flood $[9,10]$, river erosion [11] and reduction of of groundwater discharges [12,13].

In their handbook for Sustainable Urban Drainage System (SuDS), [14] highlighted that all these urbanisation processes are same in all countries including tropical countries, however each countries have variety ways of approaches on their mitigation strategies that suit to their specific conditions. Malaysia had adopted the use of SuDS to manage runoff by installing various SuDS devices and management trains throughout the country based on the Malaysian drainage manual [14,15]. Green roof is one of the SuDS devices that gradually adapted in Malaysian construction culture that mainly due to landscape aesthetic [16-18], green 
building [19, 20], thermal comfort [21-23] but SuDS itself represents the urban drainage system for water management $[24,25]$. Therefore, this paper will explores on some of the green roof performances by Malaysian studies.

\section{MALAYSIA AND THE GREEN ROOF IMPLEMENTATION}

The region of Kuala Lumpur experienced a declining in its green areas from its original 24,222 hectare of city area to only about $59.4 \%$ of the total area that equivalent to 14,386 hectares [26, 27]. Following this reduction, Kuala Lumpur exemplifies the negative effect of urbanization in the country and the urgent need to develop sustainable strategies that can maintain the green coverage in parallel with modern urbanization. Green roof has the potential to increase green areas within wasted roof in urban areas. The depletion and degradation of the environmental resources such as soil, water and air in Malaysia has also generated interest in the green roof system from most of Malaysian professionals, scholars and practical perspective [17, 28]. From the green roof projects information compiled by [28], green roof concept may not new where it have been implemented since 1992 to 2005 for the landscape purpose [17]. However, it have been recently discovered in more technical ways by professionals scholars since 2006 to 2008 and its gradually evolving since then $[17,28]$.

In $[17,29]$, once reported in their studies that the Ministry of the Federal Territories and Urban Wellbeing, Malaysia had the initiative to allocate an area of $150,000 \mathrm{~m} 2$ of traditional roofs that are to be converted to green roofs by the end of 2020. However, although green roofs gaves many benefits on environments, it is noticed that very few buildings have been adopted green roofs system [19]. This may be due to perception, challenges in development, obstacles or barriers in green roof implementation [17, 28-30].

The study also identifies the obstacles to the implementation of the green roof concept within Malaysia. One of the challenges is the absence of clear design rules and guidelines for the implementation of the concept in the country [19]. Without such guidelines, the implementation of the roof for the owners of buildings becomes a challenge. There are additional obstacles in the form of the absence of experts or green roof professionals for installation. The rest feature past failures of these roofs, complexities and costs of maintenance, high costs of installation, and the susceptibility to fire. The challenges also feature the fear for a previously unimplemented concept within the country [25].

Malaysian society is not sufficiently aware of green roof technology, hence there is a need for publicity to ensure that the technique is known by a significant population [19]. The green roof systems have been adopted in Malaysia but are not monitored scientifically, hence their performance is not sufficiently proved [31, 32].

\subsection{Green Roof Benefits}

The core aspect that should guide the decision to implement the green roof within any surrounding is the degree of benefits that the concept provides. This paper explores on the summary of the findings on the potential of environmental benefits from the use of the green roof system in Malaysia. Based on the reviews from 4 researchers findings, [17] also identified 10 beneficial factorgreen roof similar to [28] findings as listed:

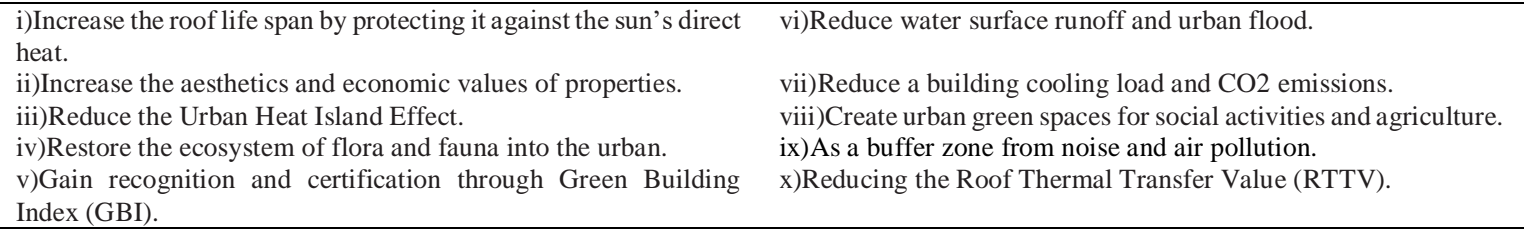

Furthermore, [33] in their study has reported that in any building construction, green roof has the opportunity to gain between $7 \%$ and $10 \%$ point from the building assessment tools such as Building Research Establishment Environment Assessment Method (BREEAM), Leadership in Energy and Environmetal Design (LEED), CASBEE, Green Mark and Green Building Index (GBI). Green roofs is well known to have direct contribution on greenery provision, greenery and roof and storm water design, noise attenuation, air pollution reduction, insulation and biodiversity of animals.

\subsection{Green Roof Configurations}

Typical green roof system consists of vegetation, growth medium and drainage layers that are placed on roof structure but the layers can be extended depending on the requirements for roof protection [34]. Typically, green roof can be classified as extensive or intensive depending on the depth of growing media. 
The extensive green roof is lightweight and has shallow layer of growth depth which normally less than 150 $\mathrm{mm}$ and planted with small plant types. While intensive green roof has deeper layer of growing media more than $150 \mathrm{~mm}$ to support larger types of vegetation such as shrubs and trees. Due to limitation on plant selection, study by [28] reported that intensive green roofs are the most common green roof implemented in Malaysia, with a dominance survey at $77.5 \%$ from total of 120 respondent, while extensive green roofs are less dominant at $22.5 \%$. However, even though the green roof layer configurations may be differ in their details, its usually features vegetation, a growth medium, a drainage and water proofing layer, as well as the final protection layer. The design of the roof must also be such that the slope achieves proper capacities of retention and porosity [26].

\subsubsection{Type of Vegetation}

Plant selection in green roof is more relying on the type of green roof itself. Shallow substrate depth of extensive green roof lead to restricted of plant species like drought tolerance succulents such as Sedum, annuals grasses, herbaceous perennials and mosses. Succulents like Sedum, mostly well suitable to extensive green roof [35-38]. In Malaysia, several research based on types of vegetation had been conducted by $[35,39-43]$ mainly focusing on the performance of the plants in reducing the stormwater runoff. Table 1 shows the summary of all the findings.

Table 1. Summary of Green Roof Vegetations used by Malaysian Studies

\begin{tabular}{ll}
\hline \multicolumn{1}{c}{ Researchers } & \multicolumn{1}{c}{ Types of Vegetation used and Findings } \\
\hline D.Kamarun et al.,(2017) [40] & - Pearl grass (Axonopus compressus (dwarf)), Philippine grass (Zoysia matrella) and \\
& Cow grass (Axonopuscompressus). \\
& - Philippine grass (Zoysia matrella) exhibited the highest potential in the reduction of \\
& water runoff \\
& -family Portulacea, Crassulaceace, and Neoregelia \\
J. Johari et al., (2011) [39] & Malaysian species except Sedum: Nephrolepis bisserrata (fern), Cynadon dactylon \\
R. Krishnan and H. Ahmad, (2014) & (grass), Kaempferia galangal (herb), and Sedum mexicanum (succulent). \\
[43] & The Creeping Ox-Eye (Wedelia Trilobata) - its a dense cover; and beach morning glory \\
K.A. Shahid et al., (2014) [41] & (Ipomoea pes-caprae) - has ability to tolerate with high ambient temperature \\
& -Five types of potted plant: syngonium podophyllum (arrowhead plants), ipomoea \\
A. Ismail et al., (2011) [44] & batatas (sweet potato), jasminum sambac, ipomoea horsfalliae (cardinal creeper) and \\
& ipomoea pes-caprae (beachmorning glory)). \\
& -Ipomoea pes capraehas ability to uptake higher amount of CO ${ }_{2}$ and resilience to higher \\
& outdoor temperatures. \\
& -Kalanchoe pinnata (cathedral bell), Arachis Pintoi (pinto peanut), Axonopus \\
& compressus (cow grass). \\
K.R. Ayub et al., (2015) [42, 45] & -Kalanchoe pinnata is the best in removing pollutant. \\
& - Axonopus compressus has good performance in flow attenuation.
\end{tabular}

\subsubsection{Green Roof Layers Materials}

In term of environment sustainability, it is important to utilize waste material into the research of green roof materials. In a research conducted by [41], it can be concluded that the palm oil clinker is suitable to replace pumice as drainage layer in green roof system. Another research had utilised rubber crumbs, palm oil shell, and polyfoam as drainage layer. Based on capabilities in peak flow attenuation and lighter green roofs, rubber crumbs are the best [31]. This is supported by [46] and [47]. Additionally, it was suggested that the impacts of a green roof are investigated under different soil conditions [24]. Summary of green roof layer materials used by Malaysian studies as shown in Table 2.

\section{GREEN ROOF RESEARCH PERFORMANCE}

This study focuses particularly on runoff and indoor temperature as the potential advantages of the implementation of the concept.

\subsection{Stormwater Performance}

In terms of stormwater retention, most studies shown that the green roof or eco-roof method could reduce peak flow and its magnitude as well as improving the water quality through soil infiltration and seepage process. The methodology and the findings for stormwater water quantity and water quality performance are shown in Table 3 and Table 4. 
Table 2. Summary of Green Roof Layer Materials used by Malaysian Studies

\begin{tabular}{|c|c|}
\hline Researchers & Findings \\
\hline R.Rashid and M.H. Ahmed, (2009) [23] & $\begin{array}{l}\text { The extensive type of full scale rooftop garden is organized by } 50 \text { nos. of greenary pot } \\
\text { plants to cover the rooftop surface. Plants are arranged densely. }\end{array}$ \\
\hline A. Ismail et al., (2011) [44] & $\begin{array}{l}\text { Field measurement on full scale concrete flat roof of a single storey detached house. } \\
\text { The the test room is } 3.05 \mathrm{~m} \times 2.73 \mathrm{~m} \times 3.05 \text { of the brick wall. The flat roof surface was } \\
\text { insulated with bituminous felt which was black in colour. }\end{array}$ \\
\hline R. Krishnan and H. Ahmad, (2014) [43] & $\begin{array}{l}\text { Extensive green roof modules in black PVC trays } 350 \times 270 \times 100 \mathrm{~mm} \text { deep of substrate } \\
\text { and } 10 \mathrm{~mm} \text { of gravel at the base }\end{array}$ \\
\hline K.A. Shahid et al., (2014) [41] & $\begin{array}{l}\text { The experimental trays with soil depth layer of } 5 \mathrm{~cm} \text { and } 4 \mathrm{~cm} \text { of drainage layer and the } \\
\text { materials used for substrate is the same and drainage layer are pumice and palm oil } \\
\text { clinker in three different sizes } 2 \mathrm{~mm}, 5 \mathrm{~mm} \text { and } 10 \mathrm{~mm} \text {. }\end{array}$ \\
\hline K.R. Ayub et al., 2015 [42] & $\begin{array}{l}\text { Small scale test beds with dimension of } 1 \mathrm{~m} \times 1 \mathrm{~m} \text {. Every beds consist of } 25 \mathrm{~mm} \text { of } \\
\text { drainage cell, cover with filter fabric (geotextile), } 50 \mathrm{~mm} \text { clean river sand (diameter } 2 \\
\mathrm{~mm} \text { ) are put on top and follow with } 150 \mathrm{~mm} \text { top soils with coefficient of permeability, } \\
\mathrm{k} \text {, value is } 9.05 \times 10^{-5} \mathrm{~cm} / \mathrm{s} \text { follow by vegetation seeds }\end{array}$ \\
\hline M. Mimezhad, et al., 2017 [22] & The extensive full scale roof on the rooftop of Heriot-Watt University building \\
\hline N.S.A. Asman, et al., 2017 [31] & $\begin{array}{l}9 \text { small scale test beds with different drainage layer different recycled waste } \\
\text { (polyfoam, rubber crump, palm oil shells), natural fibres (coconut fibre, palm oil fibre } \\
\text { and sugarcanes fibres) and one test bed as a control bed. }\end{array}$ \\
\hline
\end{tabular}

Table 3. Summary of Stormwater Performance-Water Quantity

\begin{tabular}{|c|c|}
\hline Researchers & Methodology \\
\hline S. Musa et al., (2007) [48] & $\begin{array}{l}\text { Two models of extensive flat type roof were built ( } 1 \mathrm{mx} \\
0.75 \mathrm{~m} \text { ); one with vegetated roof (test) and one non- } \\
\text { vegetated roof (control) to evaluate flow rate and } \\
\text { retention capacity. }\end{array}$ \\
\hline $\begin{array}{l}\text { A. Shaharuddin, et al., } \\
\text { (2011) [24] }\end{array}$ & $\begin{array}{l}\text { Two different surfaces; concrete roof and eco-roof ( } 645 \\
\mathrm{~m}^{2} \text { green roof).The total rainfall volume is calculated } \\
\text { using Rongfu formula. }\end{array}$ \\
\hline $\begin{array}{l}\text { K. H. Kok et al., (2011) } \\
\text { [49] }\end{array}$ & $\begin{array}{l}\text { Float method was applied to measure the surface velocity } \\
\text { of the flow. The performance of green roof in peak runoff } \\
\text { reduction was monitored by comparing the peak } \\
\text { discharge obtained from on-site experiment with the } \\
\text { standard peak discharge for district of Kuala Lumpur } \\
\text { (impervious roof) calculated from simple rational method } \\
\text { with referring to MASMA chapter } 13 \text { (DID, 2000). }\end{array}$ \\
\hline $\begin{array}{l}\text { R. Krishnan and H. } \\
\text { Ahmad, (2014) [43] }\end{array}$ & $\begin{array}{l}\text { Rainfall from weather station, water runoff }=\text { rainfall } \\
\text { (infiltrated water runoff }+ \text { surface runoff) }\end{array}$ \\
\hline
\end{tabular}

K.A. Shahid et al., (2014) The saturated hydraulic conductivity is calculated using [41]

K.R. Ayub et al.,(2015) [42]

K. H. Kok et al., (2016)[25] Darcy's law with following expression:

$$
K s\left[\frac{\mathrm{cm}}{h}\right]=\frac{V\left[\mathrm{~cm}^{3}\right] * L[\mathrm{~cm}]}{A\left[\mathrm{~cm}^{2}\right] * \Delta t[h] * h[\mathrm{~cm}]}
$$

Infiltration rate:

$$
v_{i}\left[\frac{\mathrm{cm}}{\min }\right]=\frac{V_{1}\left[\frac{\mathrm{cm}^{3}}{\mathrm{~cm}^{2}}\right]}{t[\mathrm{~min}]}
$$

With dry days of 96 hours (4 days), 4 rainfall simulation starts at $2.0 \mathrm{~L} / \mathrm{min}$ (intensity $=159 \mathrm{~mm} / \mathrm{hr}$ ) for 1 hour continuously. Outflow from the green roof is obtained after 1 hour the rainfall simulation stopped.

The simulation was done based on the local rainfall temporal patterns derived for HTC which were 10, 30, and $60 \mathrm{~min}$ in 2 years average recurrence interval. Time-Area run-off generation model was used to transform the effective rainfall to run-off hydrograph.

\section{Vegetated roof model retained $17 \%$ to 48} $\%$ storm water runoff.

Green roof helps to store $52,632 \mathrm{~m}^{3}$ volume of rainfall by using $9.8 \mathrm{~mm}$ of total rainfall as a threshold value.

The standard peak discharge calculated from simple rational method for the impervious roof was $0.0034 \mathrm{~m}^{3} / \mathrm{s}$, by comparing it with peak discharge estimated for green roof, the green roof showed peak discharge reduction up to $44 \%$.

Effectiveness in reducing water runoff fern followed by herbs, sedum and grass. Nephrolepis biserrata had highest runoff reduction at $133.4 \mathrm{~mm}$ and highest rate of water loss at $0.87 \mathrm{~g}$ followed by Kaempferia galangal with reduction at $100.5 \mathrm{~mm}$

Two parameters: saturated hydraulic conductivity and infiltration rate. Palm oil clinker has the ability to drain the water fast. The bigger size of clinker the higher value of hydraulic conductivity between 1550 $\mathrm{cm} / \mathrm{h}$ and $1800 \mathrm{~cm} / \mathrm{h}$ compared to pumice at $1650 \mathrm{~cm} / \mathrm{h}$.

Due to grass density, the highest percentage peak flow attenuation between $51 \%$ and $67 \%$.

The peak discharge of stormwater run-off was reduced up to $26 \%$ in relation to concrete tile roof. 
Table 4. Summary of stormwater performance-water quality

\begin{tabular}{|c|c|c|}
\hline Researchers & Methodology & Findings \\
\hline K.R. Ayub et al., (2015) [42] & $\begin{array}{l}\text { Runoffs generated from the simulated } \\
\text { rainfall were collected for water quality } \\
\text { parameter analysis: Total Phosphorus (TP), } \\
\text { Total Nitrogen (TN), Ammoniacal } \\
\text { Nitrogen (AN) and Potassium (K) }\end{array}$ & $\begin{array}{l}\text { All vegetation used have the ability to remove TP: } \\
20.11 \%-89.10 \% \text {, \& AN: } 59.92 \%-95.34 \% \text { Base on } \\
\text { capabilities in flow reduction and pollutants } \\
\text { removal, K.pinnata is suitable, its manage to } \\
\text { survive in long period of dry season and less } \\
\text { maintenance }\end{array}$ \\
\hline K. H. Kok et al., (2016) [23] & $\begin{array}{l}\text { Three water samples were } \\
\text { collected at the early, middle, } \\
\text { and late stage of the storm event to calculate } \\
\text { Water Quality Index (WQI). }\end{array}$ & $\begin{array}{l}\text { An average WQI of } 92 \text { (Class I) was obtained out of } \\
15 \text { samples for the run-off generated from the green } \\
\text { roof, which indicated that the run-off produced was } \\
\text { clean. }\end{array}$ \\
\hline N.S.A. Asman, et al., (2017) [31] & $\begin{array}{l}\text { The inflow from rainfall simulator are for } \\
15 \text { minutes continuously. The outflow was } \\
\text { taken for one hour continuously after the } \\
\text { simulator started with five minutes interval. }\end{array}$ & $\begin{array}{l}\text { Parameters: } \mathrm{pH} \text { value, total suspended solid (TSS), } \\
\text { turbidity and chemical oxygen demand. } \mathrm{pH} \text { values: } \\
\text { all below control under } 6.64 \text {, but for layer polyfoam } \\
+ \text { sugarcane fibre } 5.42 \text { and rubber } \\
\text { crumb+sugarcane fiber } 5.1 \\
\text { TSS: } 5 \text { layers type has larger than } 10 \mathrm{mg} / \mathrm{L} \text { (Rubber } \\
\text { Crump + coconut fibre }-10 \text {, Polyfoam + Palm oil } \\
\text { fibre - } 12 \text {, Polyfoam + sugarcane fibre }-17 \text {, and } 22 \\
\text { for Palm Oil Shells \& } \\
\text { Rubber Crumb + sugarcane fibre } \\
\text { Higher turbidity at } 10.4 \text { ahd higher COD at } 63 \text { NTU } \\
\text { was Rubber Crumb + sugarcane fibre }\end{array}$ \\
\hline
\end{tabular}

\subsection{Thermal Performance}

Green roofs have been recognised as a great means of limiting the Urban Heat Island (UHI) effect by removing heat from the air through evapotranspiration of the plants, which leads to a reduction of the temperatures of the roof surface and the surrounding air [21]. The methodology and findings obtained from thermal performance research in Malaysia are summarized in Table 5.

Table 5. Summary of Thermal Performance

\begin{tabular}{|c|c|}
\hline Researchers & Methodology \\
\hline A.Ismail et al., (2011) [44] & $\begin{array}{l}\text { Field measurement on full scale flat roof of a } \\
\text { single storey detached houseof indoor and } \\
\text { outdoor microclimates of test room with } \\
\text { different types of roof treatments }\end{array}$ \\
\hline
\end{tabular}

R.Rashid and M.H. Ahmed, (2009) [23]

M. Mirnezhad, et al., (2017) [22]
Field measurement on pot plants for every 15 minutes for internal and external data using Dickson data logger, infra red ray gun data logger and air temperature \& humidity sensor logger

Field measurement on two different depths of soil $(12 \mathrm{~cm} \mathrm{\&} 28 \mathrm{~cm})$ using thermocouples for every 10 minutes

Findings
The maximum solar radiation for the measurement
of black bare roof, green roof and white roof are
1009,1126 and $1048 \mathrm{~W} / \mathrm{m}^{2}$ respectively.
The average temperature difference between two
roofs was $6.85^{\circ} \mathrm{C}$ observed from $1 \mathrm{pm}$ to $8 \mathrm{pm}$.
Average indoor surface temperature difference
between whiteroof and black bare roof was $5.30^{\circ} \mathrm{C}$
at $4.15 \mathrm{pm}$. Green roof have the ability to lower the
indoor air temperature better than white roof by
providing shades and evapotranspiration to the roof.
Rooftop surface maximum temperature was
decreased around $11.2^{\circ} \mathrm{C}$ to $19.8^{\circ} \mathrm{C}$ in field
experiment.Green roof reduces the ceiling surface
temperature by a maximum of $3.0^{\circ} \mathrm{C}$ and on average
$1.7^{\circ} \mathrm{C}$, in comparison to bare roof. The maximum
temperature difference between indoors and
outdoors is $4.4^{\circ} \mathrm{C}$ with green roof during day time
Highest temperatures are ranging between 24.9 to
$60.7^{\circ} \mathrm{C}$ and are captured from hard roof. Green roof
with deeper soil thickness varies from 27.4 to 34.5
${ }^{\circ} \mathrm{C}$, lower soil depth green roof from 29.1 to $35.2^{\circ} \mathrm{C}$
with similar fluctuation. wet soil helps to boost soil
capacity in $\mathrm{CO}_{2}$ sequestration.

\section{VIABILITY OF RESULTS AND CONCLUSIONS}

The study concludes that the use of the green roof is a viable concept for application in Malaysia. This conclusion bases on the data showing the roof having reduced the runoff and lowered the indoor temperature for the buildings on which it was tested. However, the conclusion of viability may be limited for this particular study due to the choice data applied in the process. The study reports inaccuracies in the results collected regarding the runoff recorded following implementation of the roof. This shortcoming is attributed 
to the lack of scientific equipment suitable for the collection of data in such a context [43]. There are also shortcomings on the data on the rainfall patterns for the area. The data limitation diminishes the accuracy of the terms of the experiment, as the assumptions applied about the rain were unsuitable to the context. Therefore, the elements of this study cannot conclusively be used to generalize the assumptions about the green roof concept to the entire country or any typical tropical climate.

\section{CONCLUSIONS ON THE GREEN ROOF CONCEPT IN TROPICAL CLIMATES}

The research establishes that the concept of a green roof has been adopted in Malaysia since the early 1990's, but has not been fully embraced. The review also establishes that both intensive and extensive green roof technologies are applied. Other than the efforts of researchers and scholars, the government has also set aside a given percentage of the urban area for the establishment of the green roof technology. However, sufficient research work has not been done to establish optimal conditions for the use of green roofs in Malaysia, therefore it is necessary for the more scholarly effort to be put into establishing the most suitable way in which the technology should be applied for the maximum environmental and economic benefit.

\section{REFERENCES}

[1] Camillo P.A. \& Marco A.P. (2008). The Urban Heat Island (UHI) Effect. Retrieved at http://www.urbanheatislands.com/

[2] M. Srivanit, K. Hakao \& V. Phonekeo. "Assessing the Impact of Urbanization on Urban Thermal Environment: A Case Study of Bangkok Metropolitan”. International Journal of Applied Science and Technology, Vol 2, No 7, 2012.

[3] A.K. Tripathi and G. Mukesh.'Biochemical parameters of plants as indicators of air pollution". Journal of Environment Biology, 28, 127-132, 2007.

[4] A. Singh and M Agrawal, "Acid rain and its ecological consequences". Journal of Environmental Biology, 29(1), 1524, 2008.

[5] E. Philip, M. Rizal, M.K. and S. Siti Mariam, "Forest damage caused by acid precipitation and pollution in Malaysia." $4^{\text {th }}$ International Plantation Industry Conference \& Exhibition (IPiCEX 2014), Kuching Sarawak, 2014.

[6] M.Z. Omar and M. Rindam, "The impact of acid rain on historical buildings in Kuala Lumpur, Malaysia". Article in Design Principles and Practices 5(6), pp. 175-191. 2011.

[7] N. Lal, "Effects of Acid Rain on Plant Growth and Development Effects of Acid Rain on Plant Growth and Development," e-Journal Sci. Technol., vol. 11, no. 5 May, pp. 85-108, 2016.

[8] Z. Bakhshipour, A. Asadi, Bujang B.K. Huat, A. Sridharan, S. Kawasaki, "Effect of acid rain on geotechnical properties of residual soils". Elsevier: Soils and Foundation, 56(6), pp 1008-1020, 2016.

[9] W.C. Ngai, (1997) "Increasing flood risk in Malaysia: causes and solutions", Disaster Prevention and Management, Volume 6 Number 2, pp. $72-86$

[10] W.C. Ngai and D.J. Parker "Response to Dynamic Flood Hazard Factors in Peninsular Malaysia" The Geographical Journal Vol. 162, No. 3 (Nov., 1996), pp. 313-325 Available online: https://www.jstor.org/stable/3059653_d

[11] K.C. Chun, A. Ab. Ghani, N.A. Zakaria, R. Abdullah, "Sediment Transport in Kulim River, Malaysia”. Conference: $21^{\text {st }}$ IAHR Congress, Seoul Korea, 2005.

[12] A.F.Mohamed, W.Z. Yaacob, A.R. Samsudin, "Groundwater and soil vulnerability in the Langat Basin Malaysia", Europian Journal of Scientific Research. 27(4), pp. 1450-216, 2009.

[13] B. Bhatta, "Analysis of urban growth and sprawl from remote sensing data". Hardcover: Chapter 2, ISBN: 978-3-64205298-9, 2010. Available online: http://www.springer.com/978-3-642-05298-9

[14] S.M. Charlesworth and C.A.Booth, "Sustainable Surface Water Management: A Handbook for SUDS", John Wiley \& Sons - Technology \& Engineering - 432 pages, 2016.

[15] A.AB. Ghani, N.A. Zakaria, C.K.Chang, A.Ainan, "Sustainable Urban Drainage (SuDS) - Malaysian Experiences". $11^{\text {th }}$ International Conference on Urban Drainage Edinburgh, Scotland, UK, 2008.

[16] J. Chan,"The rise of rooftop gardens". The Star Online: Metro News, 7 Oct 2016. Available online:https://www.thestar.com.my/metro/community/2016/10/07/the-rise-of-rooftop-gardens-association-presidentdiscusses-various-landscape-design-trends-in-malay/

[17] M.H. Md Zahir, S.N. Raman, M.F. Mohamed, M. Jamiland, Z.M. Nopiah, "The perception of Malaysian architects towards the implementation of green roofs: A review of practices, methodological and future research," Universiti Kebangsaan Malaysia, Selangor, 2014.

[18] S.R.A. Rahman and H. Ahmad, Green Roofs As Urban Antidote: A Review On Aesthetic, Environmental, Economic And Social Benefits. In: 6th South East Asian Technical University Consortium Symposium, 6 - 7 March 2012., King Mongkut's University of Technology Thonburi, Thailand, 2012.

[19] M.A.Fauzi, N. A. Malek, J. Othman, "Evaluation of Green roof system for green building projects in Malaysia," In World Academy of Science, Engineering and Technology, 2013.

[20] X.S. Lee, A.R Mohd Ariffin, H. Hussein, "Assessing the green roof technology in green building rating systems," in International Building And Infrastracture Technology Conference 7-8 June, Penang, 2011.

[21] H. Kasmin, N.A Yusoff, M.H. Samsudin, N. Atan, R. Kassim, H. Ahmad, Z. Sayuti, F. Abdullah, "Preliminary Overview on Thermal Performance of Green Roof". Applied Mechanics and Materials, Vols. 773-774, pp. 1047-1052, 2015. 
[22] M. Mirnezhad, A.M.R. Aminudin, S.Y.Kong, "Thermal performance and temperature mitigation towards application of green roof in tropical climate". Chemical Engineering Transactions, Vol 56, 2017.

[23] R. Rashid and M.H. Ahmed "Thermal performance of rooftop greenery system at the tropical climate of Malaysia". DIMENSI - Journal of Architecture and Built Environment, Vol 37, No 1, pp 41-50, 2009.

[24] A. Shaharuddin, M. H. Noorazuan, and M. J. Yaakob, "Green roofs as best management practices for heat reduction and stormwater flow mitigation," World Applied Sciences Journal, Vol. 13(13), pp. 58-62, 2011.

[25] K.H. Kok, L. M. Sidek, M.F. Chow, M.R.Z. Abidin, H. Basri and G. Hayder, "Evaluation of green roof performances for urban storm water quantity and quality controls," International Journal of River Basin Management, Vol 14(1), pp. 1-7, 2016.

[26] M.F.Chow and M.F. Abu Bakar, "A Review on the Development and Challenges of Green Roof Systems in Malaysia," WASET: International Journal of Civil, Environmental, Structural, Construction and Architectural Engineering, Vol. 10 (1), pp. 16-21, 2016.

[27] M.Yusof and M.Johari, "Identifying Green Spaces in Kuala Lumpur Using Higher Resolution” Satellite Imagery. ALAM CIPTA UPM: International Journal of Sustainable Tropical Design Research \& Practice, 5:93-106, 2012.

[28] S.R.A. Rahaman, H. Ahmad and M.S.F. Rosley, "Green roof: Its awareness among professionals and potential in Malaysian market," in ASEAN Conference on Environment- Behaviour Studies, Hanoi, 2013[ab]

[29] M.H. Md. Zahir, S.N. Raman, M.F. Mohamed, Z.M. Nopiah and M. Jamil, "A discussion of Methodologies to measure the perception of malaysian architects towards the implementation of green roof system": The $3^{\text {rd }}$ International Building Control Conference, 2013.

[30] W.Z. Wan Ismail, S.S. Ahmad, H. Kamaruddin and Z. Ithnin, Green roofs benefits; perceptions by Malaysian residential highrise end users, InCIEC 2014: Proceedings of the International Civil and Infrastructure, Springer, pp. $231-241,2015$.

[31] N. S. Afizah Asman, S. Dullah, J. L. Ayog, A. K. Mirasa, and H. Djamila, "The Hydrological Performance of Lightweight Green Roofs Made From Recycled Waste Materials As the Drainage Layer," MATEC Web Conf., vol. 103, p. 04011, 2017.

[32] Z. Ismail, H. A. Aziz, N. M. Nasir, and M. Z. M. Taib, "Obstacles to adopt green roof in Malaysia," CHUSER 2012 2012 IEEE Colloq. Humanit. Sci. Eng. Res., no. Chuser, pp. 357-361, 2012.

[33] M.A. Fauzi and N.A. Malek, "Green Building assessment tools: Evaluating different tools for green roof system". International Journal of Education and Research Vol. 1 No.11 November 2013.

[34] S. Saharuddin, N. Khalil, A. A. Salleh, "Analytical review of maintenance criteria for green roof in Malaysia". Malaysian Journal Of Sustainable Environment (MySE) Vol 3 No.2 December 2017.

[35] A. Volder and B. Dvorak, "Event size, substrate water content and vegetation affect storm water retention efficiency of an un-irrigated extensive green roof system in Central Texas," Sustain. Cities Soc., vol. 10, pp. 59-64, 2014.

[36] D. B. Rowe, "Green roofs as a means of pollution abatement," Environ. Pollut. vol. 159, no. 8-9, pp. 2100-2110, 2011.

[37] F. Raimondo, P. Trifilò, M. A. Lo Gullo, S. Andri, T. Savi, and A. Nardini, "Plant performance on Mediterranean green roofs: Interaction of species-specific hydraulic strategies and substrate water relations," AoB Plants, vol. 7, no. $1,2015$.

[38] K. L. Getter and D. B. Rowe, "The role of extensive green roofs in sustainable development," HortScience, vol. 41, no. 5, pp. 1276-1285, 2006.

[39] Johari, J., Rasidi, M.H., Said, I. (2011). "Planting Technology of Green Roof for Building in Tropical Cities: A Review on Plant Selection." 5th South East Asian Technical University Consortium Symposium. Hanoi.

[40] Kamarun, D., Mohd. Tajuddin, R. and Abdullah, B. (2017). "Engineering and Technical Development for a Sustainable Environment." 1st ed. New York: Apple Academic Press, pp.1-13.

[41] K.A. Shahid, M.A. Sulaiman, N. Ghazali, W.A. Rahman and A. Zukri, "Palm oil clinker as drainage layer in green roof system under Malaysia climatic conditions" Journal of Engineering and Technology, Vol 1 (2), pp. 27-37, 2014.

[42] K.R.Ayub, A.A. Ghani, N.A. Zakaria and S. Shaharudin, "Efficiency of intensive green roofs in high intensity rainfall for stormwater treatment: selection of vegetations," in Flood Risk management, Universiti Sains Malaysia, 2015.

[43] R. Krishnan and H. Ahmad, "Influence of Low Growing Vegetation in Reducing Stormwater Runoff on Green Roofs," Int. J. High-Rise Build., vol. 3, no. 4, pp. 1-6, 2014.

[44] A.Ismail, M.H.A. Samad, A.M.A. Rahman, "The Investigation of Green Roof and White Roof Cooling Potential on Single Storey Residential Building in the Malaysian Climate". World Academy of Science, Engineering and Technology 76, 2011.

[45] Ghani, A.Ab, K.R.Ayub, C.S Leow, S.Shaharuddin, M.F.Yusof "Feasibility Study and Practicality of Green Roof for Stormwater Management in Malaysia," Short Term Grant Report 1st ed., vol. 1, ser. 1, pp. 1-80, 2016

[46] Pérez, G., Vila, A., Rincón, L., Solé, C., \& Cabeza, L. F. Use of rubber crumbs as drainagelayer in green roofs as potential energy improvement material. Applied Energy vol. 97, 347-354, 2012.

[47] Rincón, L., Coma, J., Pérez, G., Castell, A., Boer, D., \& Cabeza, L. F. (2014). Environmental performance of recycled rubber as drainage layer in extensive green roofs. A comparative Life Cycle Assessment. Building and Environment vol. 74, 22-30, 2014.

[48] S. Musa, N. A. M. A. @ Arshad, M. R. Jalil, H. Kasmin, Z. Ali, and M. S. Mansor, "Potential of stormwater capacity using vegetated roof in Malaysia," pp. 1-6, 2007.

[49] K. H. Kok, L. M. Sidek and M. R. Z. Abidin, "Evaluating the performance of green roof for stormwater management options for green technology," in UNITENSCORed, Putrajaya Campus, Malaysia, 2011. 


\section{BIOGRAPHIES OF AUTHORS}

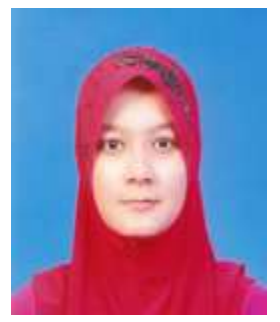

Nur Fitriah Isa currently works as a lecturer of Civil Engineering Technology at Universiti Malaysia Perlis (UniMAP) and now pursuing her PhD in Universiti Tun Hussein Onn Malaysia. After graduating cum laude from UMP with a major in civil engineering, she joined a consultation engineering firm of Perunding Amanah. She is a graduate member of the Institution of Engineers Malaysia (IEM) and a graduate engineer registered with BEM. Throughout the more than 2 years she spent in consultancy, Nur Fitriah has gained significant experience in the field of water resources including hydrologic and hydraulic modelling and environmental management through his direct involvement in several major infrastructure projects in the country. She has over 20 publications in various journals, seminars and conferences in her field of specialization and being awarded Silver Award in ITEX 2017 and Gold and Sustainability Special Award in NRIC USM.

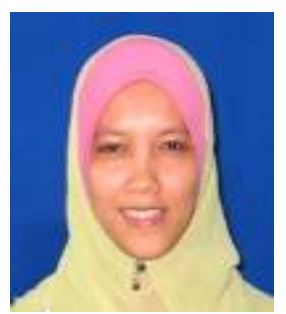

Dr. Hartini Kasmin obtained her first degree in Bachelor of Engineering (Civil Engineering) from Universiti Teknologi Malaysia (UTM). She later pursued her postgraduate studies also at Universiti Teknologi Malaysia (UTM). She received her M.Eng degree in Hydrology \& Water Resources and completed her doctoral study in 2011 specializing in Green Roof Technology in Univ. of Sheffield.). Among major research projects conducted are Stormwater Runoff Monitoring on Different Green Roof Slopes, Different Substrate Depths and Vegetation and its Performance. Dr Hartini Kasmin also focus on research and publications for few articles and journals on Flood Simulation, Green Roof Performance, Groundwater Geophysical and Hydrochemical Characteristics and Rainwater Harvesting System.

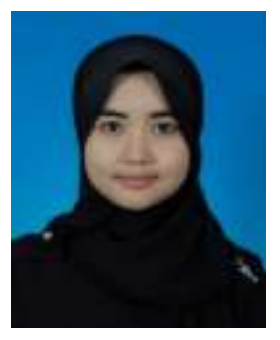

Norhaizura Yahya currently works as a lecturer of Civil Engineering Technology at Universiti Malaysia Perlis (UniMAP). She graduated in Bachelor Civil Engineering from UTHM in 2006 and pursue her study in M. Sc (Structural Engineering) from USM back in 2012. Upon her graduation, she worked with civil engineering consultation firm as a design engineer where she involved in lots of project such as residential, hotel and university construction. She is also a former senior project executive at developer company where she involved in various of development project. Her knowledge and experiences of 7 years in industry helps in her lectures and sharing the knowledge gained in design and constructions industry with the students. Apart from teaching and project supervision, Norhaizura also focus on research and publications for few articles and journals on Structural Health Monitoring, Construction Material and Sustainability.

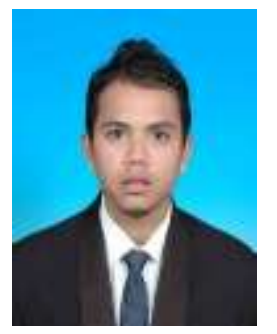

Mr. Mustaqqim Abdul Rahim is Professional Engineer (P.Eng) and Civil Engineering Lecturer at University Malaysia Perlis. His study majoring in Structural Engineering and Constructions. His work focuses on the teaching, writing, supervision and professional services. With 10 year working experience in teaching and practising engineer he has various number of publication of article, journal and chapters in digital literacy. For supervision more than 30 undergraduate student completed study and 3 Postgraduate students ongoing to complete their Master Degree.

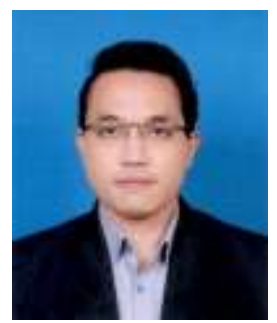

Zuhayr Md. Ghazaly is a lecturer of Civil Engineering at University Malaysia Perlis (UniMAP) and focuses his works on teaching and research development mainly in geotechnical and infrastructure field. Received his Bachelor's and Masters degree in National University of Malaysia (UKM). He is a Professional Engineer registered under the Board of Engineers Malaysia and a member of the Institution of Engineers Malaysia. Currently, published around 20 academic research papers and still going. Awarded Silver Medal for his research on The Settlement Analysis of Treated Marine Clay in 27th International Invention, Innovation \& Technology Exhibition (ITEX) 2016, Kuala Lumpur. 